\title{
Test of the Semi-Strong Efficiency Theory in the Nigerian Stock Market: An Empirical Analysis
}

\author{
Ajayi John Ayodele ${ }^{1}$, Ogbulu Onyemachi Maxwell ${ }^{2}$ \\ ${ }^{1}$ Department of Banking and Finance, Federal University of Agriculture, Abeokuta, Nigeria \\ ${ }^{2}$ Department of Banking and Finance, Abia State University, Uturu, Nigeria
}

Email address:

ayodelejohayo@yahoo.com (A. J. Ayodele), hrhogbulu@yahoo.com (O. O. Maxwell)

\section{To cite this article:}

Ajayi John Ayodele, Ogbulu Onyemachi Maxwell. Test of the Semi-Strong Efficiency Theory in the Nigerian Stock Market: An Empirical Analysis. Journal of Finance and Accounting. Vol. 5, No. 4, 2017, pp. 139-146. doi: 10.11648/j.jfa.20170504.13

Received: October 20, 2016; Accepted: November 16, 2016; Published: June 21, 2017

\begin{abstract}
This study investigates the semi- strong efficiency theory in the Nigerian stock market. The study used daily returns from the Nigerian stock market over the period of January 1, 2005, to December 31, 2013, of which about 80 companies that retained their quoting status were used as the sample for the study. A modified transfer function approach was built to show a cause and effect relationship between the output index represented by the All-Share Index of the Nigerian Stock Exchange and the input series represented by the computed index of the selected securities in the Nigerian stock market. Findings from the study showed that the coefficient of the input index is significantly different from zero implying that investors can outperform the market based on published information hence making the market be semi-strong inefficient.
\end{abstract}

Keywords: Semi-Strong, Stock Market, Input-Output, Transfer Function

\section{Introduction}

The concept of efficiency is fundamental to finance due to its implications for financial managers, investment analysts, market regulators, investors among others. Capital market efficiency can be viewed from the roles that they are expected to perform in an economy which include allocational, operational and pricing efficiencies [1, 2, 3, 4]. However, in finance, the emphasis is on pricing efficiency, although pricing efficiency implies in a limited sense operational and allocational efficiency [5]. It has been noted, however, that stock markets with higher informational efficiency are more likely to retain higher operational and allocational efficiencies [6, 7]. A market is efficient with respect on a set of information if it is impossible to make economic profits by trading on the basis by this information set. This implies that no arbitrage opportunities can be tapped using ex-ante information as all the available information has been discounted in current price. The primary role of the capital market is to allocate and channel resources from the surplus units to the deficit units. Therefore, an efficient capital market is one in which security prices quickly and fully reflect all available information [2]. Implied from this is that in an efficient market, the same rate of return for a given level of risk should be realised by all investors. The behaviour of any participant or group of participants should not influence the price of a security in the market [3]. In other words, abnormal returns (if any) should not be statistically significant from zero [1, 2 \& 8].

Market efficiency depends on the ability of traders to devote time and resources to gathering and disseminating information. Markets that are more efficient attract more investors which translate into increased market liquidity [9]. Investors care about market efficiency because stock price movements affect their wealth. More generally, market inefficiency may affect consumption and investment spending and therefore influence the overall performance of an economy [10].

The efficiency of the stock market is defined at three levels, namely- the weak, semi-strong and strong forms [1, $2]$.

According to reference [2], the weak form of market efficiency proposes that current stock prices reflect all past information. It also suggests that changes in stock prices are random and that no investment strategy that is based on past information can yield above returns to the investor. This implies that technical analysis will not be rewarded with 
above average returns.

The semi-strong form of market efficiency otherwise known as informational efficiency proposes that current stock prices incorporate all material public information about the firms issuing the security. This implies that fundamental analysis will not be rewarded with above average returns.

The strong form of market efficiency proposes that insider trading will not be rewarded as current stock prices incorporate all material public information as well as insider information [11].

\subsection{Objective of the Study}

The objective of this study is to empirically determine whether there is any significant relationship between the output series (All Share Index) and the input series (public information) in the Nigerian stock market.

\subsection{Hypothesis of the Study}

To accomplish the above objective, we formulate the following hypothesis.

$\mathrm{HO}_{1}$ : The output series (All Share Index) does not have any significant impact on the input series (public information) in the Nigerian stock market.

This paper is divided into five parts. Part 1 is the introduction, while part 2 presents the literature review. Part 3 discusses the methodology of the study while part 4 presents the discussion and results of the study while part 5 concludes the paper.

\section{Literature Review}

Some previous studies have established that the announcement of unexpected changes in dividend payments provide information affecting the market values of the companies making the changes. Reference [12] reported that managers avoid changes in dividends that would have to be reversed in the future because they believe such a reversal could have an adverse effect on the company's stock price. Subsequently, many empirical studies have tried to explain, in general, the response of the market to announce changes in dividend policy, mostly in the UK and USA [13, 14, 15, 16, $17,18,19,20,20 \& 21]$. The results of most of these studies showed that market reaction to dividend announcements is biased.

Reference [13] examined the validity of the efficient market hypothesis (EMH) by estimating the speed and accuracy with which market prices react to announcements of changes in the level of dividend payments. The author used both monthly and daily data. The sample of monthly data comprised of 1000 dividend announcements made by 625 New York Stock Exchange (NYSE) firms during the 1967-69 period. The author used a market model to estimate the abnormal performance of the samples securities and computed an index of performance API, by compounding the periodic average unexpected returns. The study concluded that the market is reasonably efficient on both monthly and daily basis in response to dividend announcements.

Reference [22] tested the information content of dividend hypothesis by analysing the abnormal performances of securities during any dividend announcements. They used a sample comprising of quarterly earnings announcements and quarterly dividend announcements of 149 industrial firms listed on the New York Stock Exchange (NYSE). Their findings for capital market reaction to the dividend announcements strongly support the view that the changes in quarterly cash dividend provide useful information beyond that provided by corresponding quarterly earnings announcements.

Also, reference [17] did a pioneering work on the impact of dividend initiation announcements on stock prices. For this study, the authors took a sample of 168 firms listed on either the NYSE or ASE, which declared a dividend for the first time in their corporate history or resumed dividend after at least a year. The study examined the information content of dividend initiation announcements in the context of the firms' information environment. By 'information environment' they mean the amount of publicly available information about any firm. They collected data for the period January 1976 to December 1987 for 80 companies which declared regular cash dividend first time in the firm's history.

For all the four proxy variables, they found that dividend initiation announcements are capable of producing highly significant abnormal returns. Moreover, the abnormality appeared to be much stronger for the low information environment firms than others. Finally, the study negates the semi-strong form of market efficiency.

Another strand of literature found evidence for immediate and post- announcement market drift as a result of dividend changes [16, $17 \&$ 20]. For example, reference [16] examined companies that initiated dividend payments for the first time, as well as those that completely omitted their dividend payments and found significant two-day abnormal stock returns of $3.95 \%$ and $-9.5 \%$ respectively. Overall, the research found that the short-run impact of dividend omissions is negative and that of initiations and dividend omissions in the USA and found that they are associated with a mean price drop of about $7 \%$ and initiations with a price increase of over $3 \%$ around the event day. These studies indicate that dividend changes convey information from corporate decision makers to the investing public.

References [14, 20 \& 18] among others have provided evidence to support post dividend announcement drift. Reference [14] found small but significant price drift after dividend changes. That is, excess returns are positive in the month following the announcement of a dividend cut. The conclusion was supported by reference [18].

Reference [23] examined the impact of earnings announcements on share prices in Nigeria around annual general meeting dates between 1986 and 1994. He used weekly stock prices and movements for 21 weeks around the event window and found out that the Nigerian capital market is not efficient in the semi-strong form as share prices still 
drift ten weeks after corporate earnings have become public information.

Reference [24] investigated the impact of dividend announcements on stock volatility rather than stock returns and found that stock volatility increases around dividend announcements, particularly final dividend announcement and interim dividend announcements when there is a dividend cut.

Furthermore, reference [25] examined the semi-strong form of the efficiency of Indian capital market in the event of the announcement of bonus issues of 145 stocks during the period from 1995 to 2000 and found evidence in favour of the semi-strong form of pricing efficiency.

Reference [26] investigated dividend announcements on the Dhaka Stock Exchange and found that there were no statistically significant abnormal returns and that dividends had no information content for stock returns and prices in the Dhaka Stock Exchange.

Reference [27] also found out that dividend announcements influence stock returns at the time of announcements, but that the short-term influence of that dividends announcements had no long-term implications. For the authors, in the long run, firms with current reductions in dividends earned excess returns.

Reference [28] analysed the earnings announcements for the Chinese equity markets by using MEGARICH approach to model changes in stock returns with event study methodology. Their findings rejected the semi-strong form of market efficiency for the Chinese markets.

Reference [29] investigated whether monetary policy announcements contained any informational value to the stock market in achieving pricing efficiency in the semistrong form by conducting event study on 50 constituent stocks of CNX Nifty Index of the Indian Stock Exchange over the period 01-01-2006 to 31-08-2007. The study documented that the impact of the announcements on the stock price on the event day was not consistently significant because sometimes such announcements had already been discounted by the market in advance. However both in the pre- and post-announcement periods, significantly positive (negative) abnormal returns were observed for good (bad) news and therefore the study failed to confirm the efficiency of the Indian stock market in its semi-strong form.

The studies of references [30, $31 \& 32]$ among others on the price reaction of the market around the announcement day of bonus issues provide strong evidence of a semi-strong form of market efficiency as the information got impounded in the prices of the respective stocks within a short period.

Analysing the stock price data of 43 Information Technology (IT) companies announcing stock splits during the financial years 2000-01 to 2006-07, Reference [33] found that the market effectively absorbed the information content of the stock split announcements before the announcement days. But in the post-announcement period the market was not able to fully capture such information.

Applying Karl-Pearson's product moment correlation coefficient and linear regression analysis on the monthly averages of BSE Sensex and National Stock Exchange (NSE) Nifty over the period, 01-08-2000 to 30-04-2010, Reference [34] found that with every moment in the FIIs' investments there was an instant reaction over the BSE and NSE allowing no scope to the investors to outperform the market, and hence they concluded that the FIIs' investments had significant role in achieving semi-strong form of efficiency of the Indian capital market.

References [35, $36 \& 37$ ] found evidence of positive abnormal returns around the announcement of stock splits and therefore drew the conclusion that the Indian stock market was pricing inefficient in its semi-strong form as the investors could make abnormal returns around the stock split announcements.

In a related study, reference [38] investigated the semistrong efficiency level of the Nigerian Stock Exchange by examining whether stock prices adjust to dividend and earnings announcements in the Nigerian Stock Exchange. The study was anchored on the Efficient Market Hypothesis (EMH) and the authors adopted the Event Study Methodology for the period of six years ranging from 20062011. The modified market model was also used to investigate whether the Nigerian Stock Market reacts efficiently to dividend and earnings announcements with respect on price adjustment. The findings of their study reveal that stock prices in the Nigerian stock market did adjust efficiently to dividend and earnings announcements in the three sub-periods covered by their sample. Also, the cumulative average abnormal returns for the different combinations of dividend and earnings in the three subperiods were not significant suggesting that the Nigerian stock market is semi-strong efficient. The results showed that the Nigerian Stock market did react efficiently to publicly available information such as dividend and earnings announcements during the three sub-periods of pre-global financial crisis (2006-2007); the global financial crisis (20082009); and the post- global financial crisis of (2010-2011). Based on these findings, the authors recommended that the Nigerian Stock market should vigorously sustain the numerous capital market reforms adopted over the years to further address the issue of adequate communication infrastructure, ease of accessibility of publicly available information, regular review of policies and regulation of the market as well as guard against the issue of insider dealing as these will enhance further efficiency of the Nigerian stock market.

A critical review of the literature above shows that there has not been consensus among the various studies carried out by various researchers hence creating a gap which this study tries to investigate.

\section{Methodology and Data}

In accordance with reference [39], the researchers developed a Transfer Function (TF) model. The general form of this model takes the following: 


$$
\mathrm{Mkt}_{\text {ind }(\mathrm{t})}=\mathrm{f}\left(\mathrm{CS}_{\text {ind1t, }}, \mathrm{CS}_{\text {ind2t }}, \mathrm{CS}_{\text {indt }}\right)+\mu_{\text {it }}
$$

Where: $\mathrm{Mkt}_{\mathrm{ind}(\mathrm{t})}$ is the market index representing the output series in period $t$.

$\mathrm{CS}_{\text {ind }}$ is the computed index of selected securities quoted on the Nigerian Stock Exchange (NSE) representing the nth publicly information i.e. the input series or causal series.

Ut is the noise term which requires an appropriating fitting of the ARIMA Model so as to transform it to become white noise. That is it becomes identically and independently (IID) compliant.

In financial time series, the commonest TF models are the zero and first order TF model while the higher order TF models are seldom and rare to encounter. We therefore, developed the zero and first order TF model for the study. Thus:

$$
\mathrm{Mkt}_{\text {ind(t) }}=\mathrm{B}_{0} \mathrm{CS}_{\text {indt-p }}+\mu_{2 \mathrm{t}}
$$

Where: $p$ represents the number of period (s) the input series is leading the output series

$\mathrm{B}_{0}$ denotes the 0 -order TF coefficient

Equation .2 is called the 0 -order TF model. However, the first order TF model can be expressed as:

$$
\mathrm{Mkt}_{\text {ind }(\mathrm{t})}=\mathrm{B}_{0}\left(1-\partial_{1} \mathrm{~L}\right)^{-1} \mathrm{CS}_{\text {ind } t-\mathrm{p}}+\mu_{3 \mathrm{t}}
$$

Equation 3 is simplified further to arrive at:

$$
\mathrm{Mkt}_{\text {ind (t) }}=\frac{\mathrm{B}_{0} \mathrm{CS}_{\text {ind } \mathrm{t}-\mathrm{p}}}{(1-\partial 1 \mathrm{~L})} \mu_{4} \mathrm{t}
$$

Where: $\mathrm{B}_{0}$ and $\partial_{1}$ are the coefficients of the first order TF model specification.

$\mathrm{L}$ is the backwards shift operator that enables us to move backwards in given series whichever the case. For example, a time series such as $\mathrm{LX}_{\mathrm{t}}$ can move back to become $\mathrm{X}_{\mathrm{t}-1}$ as we have said earlier, the expression $\partial_{1} \mathrm{~L}$ does not imply multiplication but means that $\mathrm{L}$ operates on the given time series $\left(\right.$ say $\mathrm{X}_{\mathrm{t}}$ ) to shift the series backwards one point at a time. Thus,

$\mathrm{L}^{\mathrm{n}} \mathrm{Xt}=\mathrm{X}_{\mathrm{t}-\mathrm{n}}, \mathrm{L}^{\mathrm{n}} \mathrm{L}^{2} \mathrm{X}_{\mathrm{t}}=\mathrm{X}_{\mathrm{t}-\mathrm{n}-\mathrm{z}}$. It means that $\mathrm{L}$ obeys all the laws of exponents and it can, therefore, take the form of a positive integer like $1,2,3 \ldots$. It should be clear that $1 /(1$ $\left.\partial_{1} \mathrm{~L}\right)$ is the convergence of an infinite series.

That is $\left(1+\partial_{1} \mathrm{~L}+\partial_{1}{ }^{2} \mathrm{~L}^{2}+\partial_{1}{ }^{3} \mathrm{~L}^{3}+\partial_{1}{ }^{4} \mathrm{~L}^{4}+\ldots\right)$
Therefore, equation 4 becomes:

$$
\mathrm{Mkt}_{\text {ind (t) }}=\mathrm{B}_{0}\left(1+\partial_{1} \mathrm{~L}+\partial_{1}{ }^{2} \mathrm{~L}^{2}+\partial_{1}{ }^{3} \mathrm{~L}^{3}+\ldots\right) \mathrm{CS}_{\text {indt }}+\mu_{5 \mathrm{t}}
$$

Since the L operator must obey all the laws of exponents that are routinely used in polynomial algebra, equation 5 can be modified as:

$$
\mathrm{Mkt}_{\text {ind(t) }}=\mathrm{B}_{0} \mathrm{CS}_{\text {indt }}+\partial_{1} \mathrm{~B}_{0} \mathrm{CS}_{\text {indt-1 }}+\partial_{1}{ }^{2} \mathrm{~B}_{0} \mathrm{CS}_{\text {indt-2 }}+. \mathrm{U}_{6 \mathrm{t}}
$$

Equation 6 shows a causal relationship between the current market index and previous values of the computed securities index. Thus, the notion established here is that lag values of publicly available information (input series) can be used to forecast or explain the current values of the output series (All Share Index) if all the parameters are significant.

Thus the conditions relating to this model are:

That the coefficient $\mathrm{B}_{0}$ is not statistically different from zero and the coefficients $\left(\partial_{1}{ }^{i} B_{0}\right) i$, are statistically different from zero.

On the apriori: The semi-strong form of the efficient market hypothesis (EMH) is rejected when the TF coefficients are statistically significant at a given level of confidence. Looking critically in the literature, our aim here is to identify at least one publicly available input series with $\mathrm{B}_{0}$ coefficient that leads the output series for at least 1 day for zero-order TF model or to identify at least one publicly available input series with significant parameter for the first order TF model that leads the output series, then, we can say that the semi-strong form of EMH is unambiguously rejected.

Data for the study were obtained from the Daily Official List of the Nigerian Stock Exchange spanning from January 1, 2005 to December 31, 2013. Eighty (80) companies that retained their quoting status within the range of that period were used as the sample for the study.

\section{Results and Discussion}

One of the critical propositions of this study is that public information represented by input series in equation 5 cannot be used to predict the variations in the output series which stands as a proxy for the stock market. Therefore equation 5 is a first order transfer function model. The model.is tested below.

Table 1. The Autocorrelation Function on the Series of Output Index I (0).

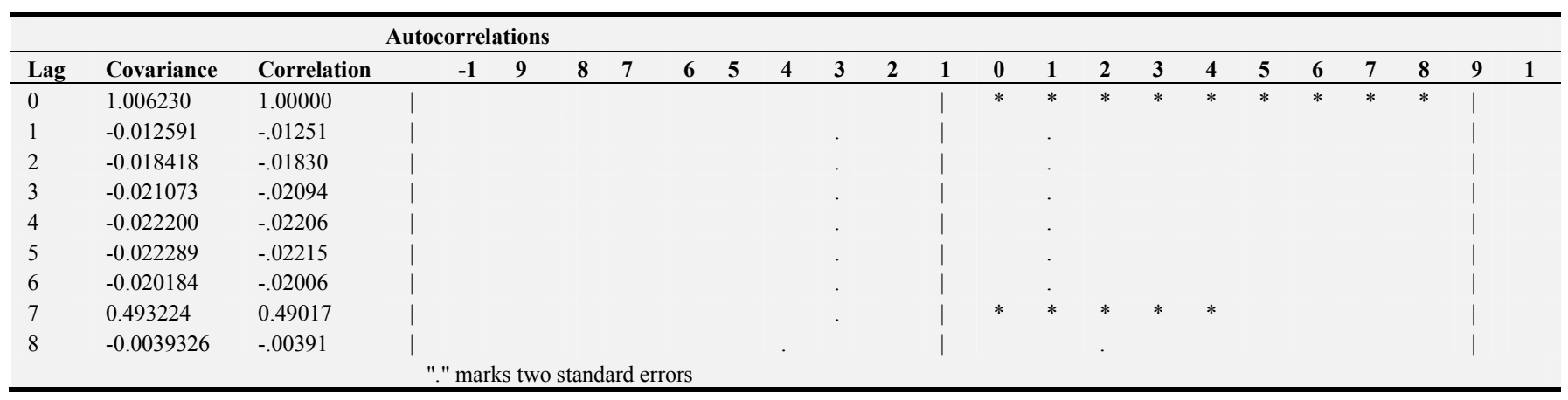


Table 1 above shows the result of the autocorrelation function up to lag eight on the series of output index. However, by the rule of default the lag length is supposed to be 24 , but in this study, the length is limited to 8 for convenience. Looking at the correlation column under lag 1 , the coefficient is -0.01251 . This means the correlation between the previous and the current output series is approximate -0.01 ; indicating an opposite movement. From lag 1 to lag 7, the correlation coefficients are found to be decaying gradually in the same direction. This is also revealed by the asterisk column. That is the last column by the right. Thus evidence has emerged to reject the hypothesis that the series is stationary at the level I (0).

Table 2. The Autocorrelation Function on the Series of Input Index I (0).

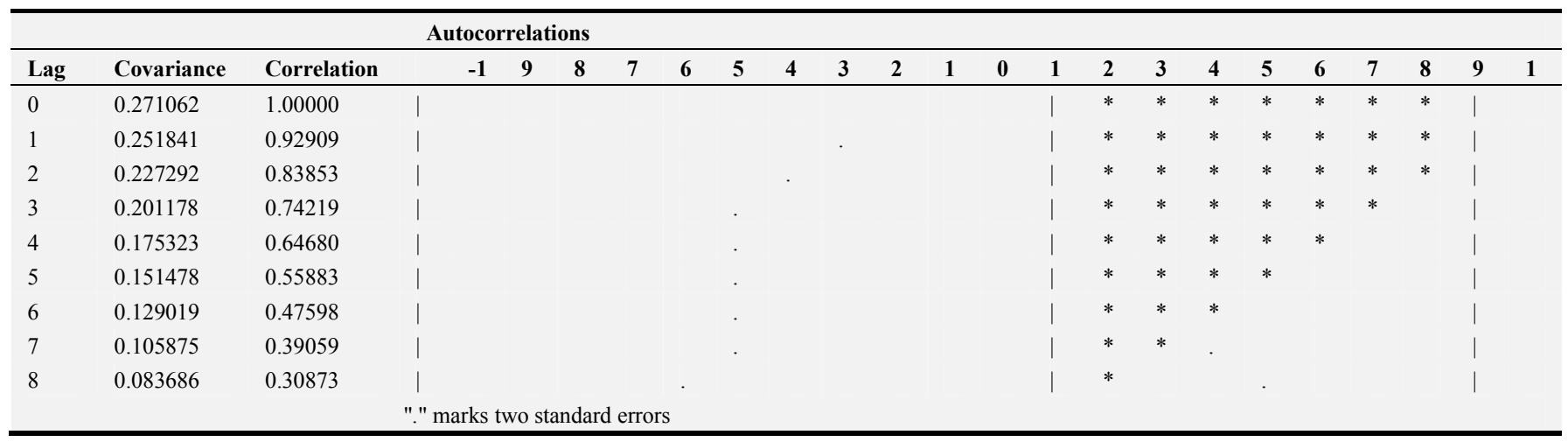

Source: Summarised by the Authors from SAS Window 9.1

The results of the autocorrelation function (ACF) of the series of input index are shown in Table 2. Virtual examination of the correlation coefficients shows that they all command positive values and simultaneously dissolved slowly as revealed by the asterisk column. Hence, there is overwhelming evidence that the series of the input index contains unit root at the level I (0).
The test for the white noise is based on the assumption that none of the autocorrelations of a series up to a specified lag is different from 0 . If for all lags this assertion is true, then there is no information in the series to model, and no TF model can be specified for the series. The autocorrelations are checked in groups of 6 . This is followed in this study for the series under investigation.

Table 3. Test for White Noise for the Series of Output Index at Level I (0).

\begin{tabular}{|c|c|c|c|c|c|c|c|c|c|}
\hline \multicolumn{10}{|c|}{ Autocorrelation Check for White Noise } \\
\hline \multicolumn{10}{|l|}{ To } \\
\hline Lag & Chi-Square & $\mathrm{DF}$ & $\operatorname{Pr}>$ ChiSq & ------. & ------ & ------ A & elations- & -- ------. & -------- \\
\hline 6 & 0.26 & 6 & 0.99 & -0.01 & -0.01 & -0.021 & -0.022 & -0.022 & -0.020 \\
\hline
\end{tabular}

Source: Summarised by the Authors from SAS Window 9.1

Table 3 above shows the result of the white noise test in the series of output index. As revealed in this table the chisquare value is very small $(0.26)$, corresponding to very large probability value (0.99). Given an alpha value of 5 percent, the hypothesis that the autocorrelations of the series are not statistically different from zero cannot be rejected meaning that the series cannot be modelled using raw data. There is the need for integration to order one as it is done in the subsequent sub-sections.

Table 4. Test for White Noise for the Series of Input Index at Level I (0).

\begin{tabular}{|c|c|c|c|c|c|c|c|c|c|}
\hline \multicolumn{10}{|c|}{ Autocorrelation Check for White Noise } \\
\hline To & Chi- & & & & & & & & \\
\hline Lag & Square & $\mathrm{DF}$ & $\operatorname{Pr}>$ ChiSq & ------. & ------------- & Autoc & & -------- & -------- \\
\hline 6 & 347.16 & 6 & $<.0001$ & 0.92 & 0.83 & 0.742 & 0.647 & 0.559 & 0.476 \\
\hline
\end{tabular}

Source: Summarized by the Authors from SAS Window 9.1

The ACF results depicted in Table 4 show a large chisquare statistics 347.16 and probability value .0001 . The probability is approximately zero implying that the hypothesis in favour of the series of the input index up to lag 6 has autocorrelations that are significantly different from zero cannot be rejected. Thus, the series can be modelled using TF specification but the fact that it is not stationary poses a serious doubt on the estimation value of such specification since it may lead to bias and inconsistent estimator. There is the need to also differentiate the series. 
Table 5. The Autocorrelation Function on the Series of Output Index at First Difference I (1).

\begin{tabular}{|c|c|c|c|c|c|c|c|c|c|c|c|c|c|c|c|c|c|c|c|c|c|c|c|c|}
\hline Lag & Covariance & Correlation & -1 & 9 & 8 & 7 & 6 & 5 & 4 & 3 & 2 & 1 & 0 & 1 & 2 & 3 & 4 & 5 & 6 & 7 & 8 & 9 & 1 & o \\
\hline 0 & 1.506075 & 1.00000 & 1 & & & & \multirow{6}{*}{ * } & & & I & * & * & $*$ & $*$ & $*$ & * & $*$ & $*$ & * & I & & & & 0 \\
\hline 1 & -0.459033 & -.30479 & | & & & & & $*$ & $*$ & | & . & & & & & & & & & | & & & & 1 \\
\hline 2 & -0.0009841 & -.00065 & 1 & & & & & . & & | & & . & & & & & & & & | & & & & 2 \\
\hline 3 & -0.0008752 & -.00058 & | & & & & & . & & | & & . & & & & & & & & | & & & & 3 \\
\hline 4 & -0.0010682 & -.00071 & | & & & & & . & & | & & . & & & & & & & & | & & & & 4 \\
\hline 5 & -0.0036865 & -.00245 & 1 & & & & & . & & | & & . & & & & & & & & | & & & & 5 \\
\hline 6 & -0.516044 & -.34264 & | & & & & \multirow[t]{3}{*}{ * } & $*$ & $*$ & | & & . & & & & & & & & | & & & & 6 \\
\hline 7 & 0.510423 & 0.33891 & | & & & & & . & & 1 & * & * & $*$ & * & & & & & & 1 & & & & 7 \\
\hline 8 & 0.0012195 & 0.00081 & 1 & & & & & & . & | & & & . & & & & & & & | & & & & 8 \\
\hline \multicolumn{25}{|c|}{ "." marks two standard errors } \\
\hline
\end{tabular}

Source: Summarised by the Authors from SAS Window 9.1

The results of the ACF on the output series at first difference are shown in Table 5. A critical view of the correlation coefficients in the third column shows they decay rapidly in either direction. This is also confirmed in the asterisk column for emphasis sake. Therefore, the authors justify that the series of the output index is stationary at first order I (1). Since the series is now stationary when integrated to order 1 , there is the need to check if it can be modelled using first- order TF specification.

Table 6. Test for White Noise for the Series of Output Index at First Difference I (1).

\begin{tabular}{|c|c|c|c|c|c|c|c|c|c|}
\hline \multicolumn{10}{|c|}{ Autocorrelation Check for White Noise } \\
\hline To & Chi-Square & DF & $\operatorname{Pr}>$ ChiSq & ------- & ----------------- & Autoco & ns-------. & (------- & ------ \\
\hline \multicolumn{10}{|c|}{ Lag } \\
\hline 6 & 23.78 & 6 & 0.0006 & -0.305 & -0.001 & -0.001 & -0.001 & -0.002 & -0.343 \\
\hline
\end{tabular}

Source: Summarised by the Authors from SAS Window 9.1

The white noise test results for the series of output index are reported in Table 6 . The chi-square statistics (23.78) is asymptotically large with desired probability value $(0.0006)$.
This simply means that the first difference of the output series is fitted for our candidate TF model for this study.

Table 7. The Autocorrelation Function on the Series of Input Index at First Difference I (1).

\begin{tabular}{|c|c|c|c|c|c|c|c|c|c|c|c|c|c|c|c|c|c|c|c|c|c|c|c|c|}
\hline \multicolumn{25}{|c|}{ Autocorrelations } \\
\hline Lag & Covariance & Correlation & & -1 & 9 & 8 & 7 & 6 & 5 & 4 & 3 & 2 & 1 & $\mathbf{0}$ & 1 & 2 & 3 & 4 & 5 & 6 & 7 & 8 & 9 & 1 \\
\hline 0 & 0.032842 & 1.00000 & | & & & & & & | & $*$ & * & $*$ & $*$ & $*$ & $*$ & $*$ & $*$ & $*$ & $*$ & $*$ & $*$ & $*$ & | & \\
\hline 2 & 0.0015532 & 0.04729 & | & & & & & . & | & $*$ & . & & & & & & & & & & & & 1 & \\
\hline 3 & -0.0003911 & -.01191 & | & & & & & . & | & & . & & & & & & & & & & & & | & \\
\hline 4 & -0.0020013 & -.06094 & | & & & & . & $*$ & | & & . & & & & & & & & & & & & | & \\
\hline 6 & 0.00079730 & 0.02428 & 1 & & & & . & & 1 & & . & & & & & & & & & & & & I & \\
\hline 7 & -0.0020190 & -.06148 & | & & & & . & * & | & & . & & & & & & & & & & & & | & \\
\hline 8 & -0.0006181 & -.01882 & | & & & & . & & | & & . & & & & & & & & & & & & | & \\
\hline \multicolumn{24}{|c|}{ "." marks two standard errors } & \\
\hline
\end{tabular}

Source: Summarised by the Authors from SAS Window 9.1

Table 7 reveals the results of the ACF in the series of the input index at first difference up to lag 8 . The function presents correlation coefficients that decay rapidly. Hence the null hypothesis that the series has a unit root at first difference is rejected. The proposed TF model for this study can now be estimated using first difference values of both the output and input series. Thus the TF model adopted in this study is referred to as Autoregressive Integrated Moving Average ARIMA (111).

Test of Hypothesis

Hypothesis: The output series (All Share Index) does not have any significant impact on theinput series (public information) in the Nigerian stock market.

The hypothesis is tested in Table 8 below: 
Table 8. The Relationship between the Output and Input Index.

\begin{tabular}{lllllll}
\hline \multicolumn{7}{c}{ Conditional Least Squares Estimation } \\
\hline Standard & \multicolumn{7}{c}{} & & \\
\hline Parameter & Estimate & Error & t Value & Lag & Variable & Shift \\
\hline MU & -0.56926 & 1.72271 & -0.33 & 0 & output & 0 \\
NUM1 & 0.61354 & 0.37439 & 1.64 & 0 & input & 0 \\
NUM1,1 & 0.38297 & 0.55507 & 0.69 & 1 & input & 0 \\
NUM1,2 & -0.03740 & 0.55504 & -0.07 & 2 & input & 0 \\
NUM1,3 & -0.13230 & 0.37103 & -0.36 & 3 & input & 0 \\
\hline
\end{tabular}

Source: Summarised by the Authors from SAS Window 9.1

The estimated values of equation 5 are reported in Table 8. The lag values of the input index are expressed as explanatory variables of the output index. The observed tstatistics for the input index up to lag 3 are 1.64, 0.69, $0.07 \&-0.36$ respectively while the critical t-statistics at 10 percent is about 1.29. By comparison, the t-value of the input index at order (0) is larger than the critical t-value. This means that publicly published information captured by the input index commands significant effect on the stock market (represented by the output index); thereby negating the null hypothesis of the study that the output index is not significantly captured by input index. On the contrary, the semi-strong market hypothesis stipulates that published information does not influence stock market prices; so no investor can take advantage of published information to outperform the market or make a gain at the expense of other participants. Thus, our findings here provide evidence in support of semi-strong form inefficiency in the Nigerian stock market. The results are however in contrast to the findings of Ogege, Ogbulu and Isu (2015) who found evidence of semi-strong efficiency in the Nigerian stock market by adopting the Event study methodology over a period of six years.

\section{Conclusion}

This study x-rays the semi- strong efficiency theory in the Nigerian stock market through the input and output index. An investigative research design was utilised for the study. The study used the daily official list of the Nigerian stock market over a period of January 1, 2005, to December 31, 2013. The authors used a first order transfer function (TF) model specification by Joseph (1986) to investigate the relationship between output and input index. The TF model adapted for the study is Autoregressive Integrated Moving Average ARIMA (111). A hypothesis was formulated to show whether the output series has any significant impact on the input series in the Nigerian stock market. Results from the study showed that public information captured by the input index has a significant impact on the Nigerian stock market All Share index (output series).Thus, investors can beat the market hence making the market to be semi- strong inefficient.

Based on these findings, the government through the Nigerian Securities and Exchange Commission should increase its efforts to deepen the international market size of the Nigerian capital market by introducing more attractive investment media into the market. Internationally hybrid securities such as options, futures among others should be floated in the Nigerian stock market. The government can promote the efficiency of the Nigerian stock market through surveillance. There is the need for the Nigerian Securities and Exchange Commission to further monitor the Nigerian stock exchange to prevent insider abuse. The authorities of the Nigerian stock market should float asset- backed securities to provide liquidity for the already traded stocks on the market.

\section{References}

[1] Fama, E. F. (1970). Efficient capital markets: A review of theory and empirical work, Journal of Finance, PP 383-417.

[2] Fama, E. F. (1991). Efficient capital markets: II, Journal of Finance, 46 (5, December): PP 1575-617.

[3] Khoury, J. S. (1983). Investment Management Theory and Application, New York, Macmillan Publishing.

[4] Olowe, R. A. (1998), Stock splits and the efficiency of the Nigerian stock market. African Review of Money, Finance and Banking, 1 (2): PP 97-125.

[5] Olowe R. A (2011). Financial Management, Forthright Publishers: Lagos. Copeland, T. E. \& Weston, J. F. (1983). Financial Theory and Corporate Policy, California, Addison Wesley Publishing.

[6] Muslumov, A. et al. (2004). Evolving market efficiency in Instabul stock exchange, Social Science Research Network, SSRN-id 8900077.

[7] Okpara, G.C. (2010). Stock market prices and the random walk hypothesis- Further evidence from Nigeria, Journal of Economics and International Finance vol. 2 (3): PP 49-57.

[8] Fox, A. F \& Opong, K. K (1999). The impact of board changes on shareholders wealth: Some U. K evidence. Corporate Governance, An International Review, 7 (Oct): PP 385-96.

[9] Osei, K. A (1998). Analysis of factors affecting the development of an emerging market: The case of Ghana stock exchange, AERC Research Paper No. 76, African Economic Research Consortium, Nairobi.

[10] Adelegan, O. J. (2009). Price reactions to dividend announcements on the Nigerian stock market, AERC Research Paper 188, July. 
[11] Reilly, F. K. \& Brown, K. C. (2006). Investment Analysis and Portfolio Management, $8^{\text {th }}$ edition, South Western Publishing Company.

[12] Lintner, I. (1956). Distribution of income corporations among dividend, retained earnings and taxes, American Economic Review, 46 (May), PP 99- 118.

[13] Pettit, B. (1972). Dividend announcements, security performance and capital market efficiency, Journal of Finance, XXVII: PP 993-1007.

[14] Charest, G. (1978). Split information, stock returns and market efficiency I, Journal of Financial Economics, Vol. 6, PP. 265-296.

[15] Bernanrd, V. I. \& Thomas, J. K. (1990). Evidence that stock prices do not fully reflect the implications of current earnings for future earnings. Journal of Accounting and Economics, 13, PP. 305-340.

[16] Healy, P. \& Palepu, K. (1988). Earnings information conveyed by dividend initiation and omissions, Journal of Financial Economics, 21: PP. 149-175.

[17] Asquith, P. and Mullins D. W. (1983). The impact of initiating dividend payments on shareholder's wealth", Journal of Business, 56: PP.77-79.

[18] Christie, W. G. (1990). Dividend yield and expected returns: The zero puzzle, Journal of Financial Economics, 28: PP 95125 .

[19] Dhillion, U. S. \& Johnson, H. (1994). The effect of dividend changes on stock and bond prices, The Journal of Finance, 49 (1 March), PP. 281-290.

[20] Michaely, R. et. al (1995). Initiations and omissions: Overreaction or drift? The Journal of Finance, 50 (2, June) PP. 573-607.

[21] Amihud Y. \& Murgia, M. (1997). Dividend taxes and signaling: Evidence from Germany. The Journal of Finance, LII (1, March) PP. 397-408.

[22] Aharony, J. \& Swary, I. (1989). Quarterly dividend and earnings announcements and stockholders' returns: An empirical analysis, The Journal of Finance, 35 (1), March: PP 1- 12 .

[23] Oludoyi, S. B. (1999). Capital market efficiency and the effects of earnings announcements on share prices in Nigeria, Unpublished PhD Thesis, University of Ibadan, Nigeria.

[24] Acker, D. (1999). Stock return volatility and dividend announcements: Review of Quantitative Finance and Accounting, 12, PP. 221-242.

[25] Gupta, V. (2003). Announcement effects of bonus issues on equity prices: The Indian experience, Indian Journal of Finance and Research, Vol. 13, No. 1 \& 2.
[26] Uddin, M. H. \& Chowdhury, G. M. (2005). Effect of dividend announcement and shareholders value. Evidence from Dhaka stock exchange, Journal of Business Research, 7, PP. 61-72.

[27] Gunasekarage, A. \& Power, D. M. (2006). Anomalous evidence in dividend announcement effect, Managerial Review, 32, PP.209-226.

[28] Kong, S. \& Taghavi, M. (2006). The effect of annual earnings announcements on the Chinese stock markets, International Advances in Economic Research, 12, PP. 318-326.

[29] Agrawal, G. (2007). Monetary policy announcements and stock price behavior: Empirical Evidence from CNX Nifty, Decision, Vol. No. 2, PP. 133-153.

[30] Obaidullahi, M. (1992). How do stock prices react to bonus issues? Vikalpa, Vol. 17, No. 1, PP. 17-22.

[31] Rao, S. N. (1994). The adjustment of stock prices to corporate financial policy announcements, Finance India, Vol. 8, No. 4 PP. 941-953.

[32] Mishra, A. K. (2009). An empirical analysis of market reaction around the bonus issues in India. Bonus Issue Paper.

[33] Raja, S. \& Clement, S. (2009). Testing the semi-strong of Indian stock market with respect to information content of stock split announcements- A study of IT industry, International Research Journal of Finance \& Economics, 25, PP. 1-14

[34] Khan, A. Q and Sana, I (2010. Testing semi-strong form of efficient market hypothesis in relation to the impact of foreign institutional investors' (Fils)' investments on Indian capital market, International Journals of Trade, Economics and Finance, Vol. 1, No 4: PP 373-379.

[35] Gupta, A. \& Gupta, O. P. (2007). Market reaction to stock splits: Evidence from India, The IUP Journal of Applied Finance, Vol. 13, No. 1: PP. 5-22.

[36] Kaur, P. (2010). Valuation effect of stock split in India: Case of BSE sensex constituents, Finance India, Vol. XXIV, No. 3: PP. 813-831.

[37] Ray, K. K. (2011). Market reaction to bonus issues and stock splits in India: An empirical study, The IUP Journal of Applied Finance, Vol. 17, No. 1: PP. 54-69.

[38] Ogege, S., Ogbulu, O. M. \& Isu, H. O. (2015). Earnings and dividend announcements, semi - strong efficiency and the Nigerian stock market: An empirical investigation, Archives of Business Research, Vol. 3, No 4, PP.104-123, doi: 10.14738/abr.34.1366.

[39] Joseph, W. C. (1986). An alternative semi-strong form test of the efficient market hypothesis by a transfer function approach, Unpublished MBA Dissertation, Simon Fraser University, Canada. 